\title{
Safeguarding the Buddha Statues in Bamiyan and the Sustainable Protection of Afghan Cultural Heritage
}

\author{
Mounir Bouchenaki
}

\begin{abstract}
Sadly, the cultural heritage of Afghanistan has suffered cruelly from the conflicts and disasters. But the most dramatic destruction was the one decided by the chief of the Taliban regime, Mullah Omar, on 26 February 2001 for the destruction of the two giant Buddha statues in the carved during the fifth century AD in the Bamiyan Valley. Under the authority and support of the UNESCO Director-General Koïchiro Matsuura, a series of actions were undertaken to mobilize political and religious personalities of the Islamic States that could influence the Taliban. The Taliban announced their decision 1 week to 10 days before Aïd el Adha, one of the most important Islamic festivals, commemorating the Abraham Sacrifice, fixed on March 8, 2001. UNESCO Director-General was able to speak by telephone with President of Egypt, Hosni Mubarak, who immediately accepted to facilitate a mission of Egyptian religious personalities led by Sheikh Al-Azhar to Kandahar in order to persuade the Taliban over their concerns for errors in interpreting Islamic law. To respond to the numerous questions that UNESCO received after the destruction of the Buddhas of Bamiyan, a conference of experts in Islamic law was organized in Qatar, end of December 2001, at the occasion of regular meeting of the Ministers of Culture of the Islamic World, which proclaimed the "Doha Declaration on Islam and Cultural Heritage".
\end{abstract}

Keywords Afghanistan · Buddhas · Bamiyan · Taliban · UNESCO · Islam · Doha Declaration

Published jointly by the United Nations Educational, Scientific and Cultural Organization (UNESCO), 7, place de Fontenoy, 75007 Paris, France, the UNESCO Office in Kabul, ICON Compound, Supreme Road, Off Jalalabad Road, PD 9, Kabul, Afghanistan, and Springer Nature Switzerland AG, Gewerbestrasse 1, 6330 Cham, Switzerland.

M. Bouchenaki $(\square)$

Paris, France 


\section{A Treasure of Histories}

Many cultural treasures are scattered across the country, such as the Kanishka/ Zoroastrian site of Surkh Kotal; the ninth-century Nine Domes of the Mosque Haji Piyada; the twelfth-century Minaret of Jam; the walled city of heart; the site of Mes Aynak, an immense historical site home to thousands of representations of the Buddha, located south of Kabul; and the famous Baburs Gardens, in Kabul, which were recently rehabilitated through a programme financed and coordinated by the Aga Khan Trust for Culture, to name but a few.

Among these rich cultural heritage sites and historic relics, it is important to mention the monumental Buddhas sculpted in the cliffs of Bamiyan during the end of the fifth or early sixth century A.D, according to most recent dating by C14, reported by Carlotta Gall (2006). The Buddhas of Bamiyan were two monumental statues of standing Buddhas carved into the side of a cliff in the Bamiyan Valley of central Afghanistan, representing the classic blended style of Indo-Greek art (UNESCO 2012). These two prominent statues were giants measuring 55 and 37 meters high, respectively, and representing the largest examples in the world of representations of standing Buddhas carved in stone.

Sadly, the cultural heritage of Afghanistan has suffered tremendously from the conflicts and disasters that have afflicted the country for more than a quarter of century. This ongoing war and civil unrest has claimed the lives of hundreds of thousands, and it has displaced populations and provoked significant cultural disasters. The irreplaceable collections of the Kabul Museum, as well as numerous historical and archaeological sites, have been the victim of large-scale pillage and vandalism. Throughout history, destruction and loss of cultural heritage have been "collateral" effects of armed conflicts. Extensive looting and forced transfers of cultural objects have accompanied almost every war since ancient times. In modern times, aerial bombardments during World War II and the more than one hundred armed conflicts that have plagued the world since 1945 have contributed to the destruction and disappearance of much cultural heritage of great importance for countries of origin and for humanity as a whole (Francioni and Lenzerini 2003). One of the most destructive decisions was made by the chief of the Taliban regime, Mullah Omar, on February 26, 2001.

\section{The Buddhas in Crisis}

UNESCO received the news through a telephone call from the Ambassador of Greece to Pakistan, who was on mission to Afghanistan, in order to meet with members of the Taliban government. In 2001, I was the Assistant Director-General for Culture at UNESCO and was accompanying the former UNESCO Director-General Mr. Koïchiro Matsuura on an official visit to Algeria, when I received a call from my colleague, Mrs. Lyndel Prott, Director of the Division of Cultural Heritage and 
expert in international law. The Assistant Director-General of Culture had been previously involved in similar situations of cultural heritage destruction, such as the destruction of the Mostar Bridge in Bosnia-Herzegovina.

She informed me of the message from the Greek Ambassador to Pakistan, warning UNESCO about the imminent destruction of the Buddhas following an order by the Taliban leader, which I immediately relayed to the Director-General. During the return flight from Algiers to Paris, Mr. Matsuura asked me to deal with this issue and to urgently propose a strategy of response. It was not the first time that the Afghan Taliban authorities had issued such menaces. The threat had been already raised in 1998, and UNESCO, through its preceding Director-General, Federico Mayor, had called for respect of this ancient heritage. At that time, a Taliban commander had already caused damage to the head of the smaller Buddha and placed explosives at the base of the niches housing both Buddhas. It seemed as though time was against us.

During the same period, Paul Bucherer-Dietschi, a Swiss architect, had started laying the foundations for the "Afghanistan Museum", also known as "Bibliotheca Afghanica". He had done so at his own expense, creating a "cultural sanctuary" in a small town named Bubendorf, near Basel (Switzerland), in order to protect Afghan artefacts being illegally traded through international illicit trafficking networks. In 1998, he negotiated an agreement between the Taliban and the Northern Alliance. Through the intervention of the Swiss delegation to UNESCO and the approval of the Swiss Parliament, this safe haven was finally recognized by UNESCO, albeit reluctantly because UNESCO was not willing to encourage trafficking of cultural objects while having the responsibility to promote the 1970 Convention concerning the illicit traffic of cultural properties.

In July 1999, Mullah Omar issued a decree for the protection of the Buddhas. According to a journalist from The Guardian, Mullah Omar noted that "there are no more Buddhas in Afghanistan and that statues could be an example of a potential major source of income for the nation, from international visitors" (Harding 2001). However, in December 1997, the World Heritage Committee, the governing body of the 1972 UNESCO Convention on the Protection of World Cultural and Natural Heritage, had adopted a resolution at its Naples meeting expressing concern over reports about threats by the Taliban regime with regard to the Buddhist statues of Bamiyan. The resolution, adopted unanimously following a proposal by Italy, stressed that "the cultural and natural heritage of Afghanistan, particularly the Buddhist statues in Bamiyan [...] for its inestimable value, [has to be considered] not only as part of the heritage of Afghanistan but as part of the heritage of humankind" (UNESCO 1997, p. 34). Later, in July 2001, Mullah Omar changed his mind and took a different decision, aiming at the demolition of the Buddha statues.

Upon his return to Paris, on February 28, 2001, UNESCO Director-General Koïchiro Matsuura termed the new decision to destroy the Afghanistan statues a "true cultural disaster" and demanded that Afghan Government instantly halted the destruction of this invaluable heritage. Warikoo (2002, p. 9) argues that "To blindly destroy the statues will not alter history, only deprive the future Afghanistan of one of its riches. I ask that all those concerned, and the highest leader of the Afghans themselves, to immediately take all measures for the protection of this unique 
cultural heritage. The loss of any Afghan statues, and particularly the Buddhas of Bamiyan, would be a loss for all humanity". He also (2002) added that "the authors of such an irredeemable act would bear a heavy historic responsibility to the Afghan people" and concluded that "it is not in this kind of action that they will gain credibility in public opinion or in the international community".

On March 1, 2001, the Director-General organized a number of meetings with the Permanent Delegates to UNESCO, particularly those from the Asian countries where Buddhist communities were shocked and saddened by the news emerging from Afghanistan, as well as those from Islamic countries. Representatives from India, Japan and Sri Lanka were approaching the Afghanistan leader and his government, trying to change the order. The Permanent Delegations at UNESCO also urged the Director-General to take immediate action. These meetings took place under added tension since the Taliban had chosen to announce their decision 1 week before Aïd-el-Kébir (also called Aïd el Adha), one of the most important Islamic religious festivals commemorating the Abraham Sacrifice. This meant that most Islamic nations were occupied with the religious holiday and that the pilgrimage to Mecca, in Saudi Arabia, had already begun. Such timing with respect to the religious calendar would continue to create difficulties in contacts between the UNESCO Secretariat and a number of authorities in the Islamic world.

Mr. Koïchiro Matsuura then formed a crisis unit at his cabinet level, gathering Mrs. Françoise Rivière, Chief of Cabinet; Mr. Ahmed Sayyad, Assistant DirectorGeneral for External Relations; Mr. Francesco Bandarin, Director of the World Heritage Centre; and myself, Assistant Director-General for Culture. The DirectorGeneral appointed me as the coordinator of actions to respond to the order for the destruction of the Bamiyan Buddha statues. On that same day, March 1, I contacted the former French Ambassador to Pakistan, Mr. Pierre Lafrance, who knew Afghanistan well and was a scholar on Central Asia and who was also fluent in the diverse languages of Afghanistan. He immediately accepted the proposal by the Director-General to act as his Special Envoy to Afghanistan. In less than $24 \mathrm{~h}$, thanks to the support of the Minister of Foreign Affairs of France and the Minister of the Interior of Pakistan, Mr. Lafrance arrived in Kandahar, where most of the members of the Taliban government were gathered.

On March 2, 2001, at the opening of the International Colloquium on Central Asian Heritage, which coincidentally took place at UNESCO Headquarters, Mr. Matsuura declared "I have chosen a person who is well known and respected in the region, with great knowledge of issues in the Middle East and Central Asia" (Bouchenaki 2015, p. 234). During this colloquium, the Director-General was able to provide an update on the initiatives that had already been taken to "reverse the absurd direction that the Kabul authorities have initiated".

Within the Secretariat for the UNESCO Culture Sector, I formed a working group composed of Ms. Paola Leoncini-Bartoli, Chief of the Executive Office for the Assistant Director-General for Culture, and Mr. Christian Manhart, Programme Specialist, who assisted me in contacts with the various Permanent Delegations and major non-governmental organizations specialized in safeguarding cultural heritage, in particular ICOMOS, ICOM, and the Society for Preservation Protection of Afghan's Cultural Heritage (SPACH). I would like to stress that this was a true race 
against time, to respond as effectively as possible to the decision of destroying the Bamiyan Buddhas before the Aïd el Adha, which would take place on March 8, 2001.

It is now well-known that the Taliban themselves confirmed that, pursuant to an edict by their supreme leader Mullah Mohammed Omar, on February 26, 2001, destruction operation had actually been started. The text of the edict (The Guardian 2001) clearly expresses the beliefs and intentions pursued by the Taliban and does not need further comment:

Based on the verdict of the clergymen and the decision of the supreme court of the Islamic emirate all the statues around Afghanistan must be destroyed. Because God is one God and these statues are there to be worshipped and that is wrong. They should be destroyed so that they are not worshipped now or in the future.

During a meeting with the media, on March 6, 2001, I listed the activities that for several decades had received support from UNESCO to safeguard Afghan heritage and discussed the possibility of creating a special assistance fund for the Afghan historic monuments and sites, as well as the National Museum, in Kabul. I insisted on the fact that the Taliban decision had encountered unanimous condemnation in all parts of the world, including both within nations with a notable Buddhist community and Islamic nations, and that the latter had indicated that there was no serious religious argument that could serve as a basis for such an iconoclastic gesture.

With the authority and support of the UNESCO Director-General, a series of actions were carried out in view of rapidly mobilizing political and religious personalities that could influence the Taliban regime. In that sense, the Arab Group at UNESCO issued a release calling for "international mobilization for concrete actions to end this unprecedented gesture, which concerns invaluable treasures of universal value".

It should be noted that Ambassador Pierre Lafrance had telephoned from Kandahar to inform that, despite his meeting with the Minister of Culture and the Minister of Religious Affairs of the Taliban government, the decision to destroy the Buddha statues was related to religious interpretations and that he could not intervene any further. However, he continued his travels as Special Envoy of the UNESCO Director-General and went to Saudi Arabia, a country which might have some influence with the Taliban, and then returned to Paris to report on his mission. It should be noted that a message of congratulations from Mr. Jacques Chirac, then President of the French Republic, was sent to UNESCO praising the decision in sending Ambassador Pierre Lafrance as Special Envoy to Afghanistan.

With the support of the Arab and Muslim Ambassadors to UNESCO (particularly Iran, Morocco, Qatar and Syria), I succeeded in discussing the facts with important Islamic religious authorities, who went on to express a different view to that expressed by the Afghan Taliban. I would like to express my own sincere thanks for the important role played by the Ambassadors of those countries, who worked devotedly alongside UNESCO in these efforts.

H.E. Ms. Aziza Bennani, Ambassador of Morocco to UNESCO, facilitated my contacts with the Secretary General of the Organization of Islamic Cooperation, Dr. Abdelouahed Belkeziz. H.E. Mr. Ahmad Jalali, Ambassador of Iran to UNESCO, as an expert of philosophy and Islamic thought, provided me with important bibliographic references, in particular a text of a scholar of the eleventh century, Al-Biruni, 
who visited Bamiyan. H.E. Mr. Ali Zainal, Ambassador of Qatar to UNESCO, facilitated the contacts with Qatari authorities by arranging a special flight to Afghanistan. H.E. the late Mr. Amine Esber, Ambassador of Syria to UNESCO, provided me with invaluable assistance in organizing the meeting of experts in Islamic law that was held in Doha, Qatar, in December 2001. Thanks to his invaluable support, I was able to contact Sheikh Yusuf al-Qaradawi in Doha, considered one of the most respected living religious scholars of the Arab world, and to persuade him to travel to Afghanistan. Sheikh Yusuf al-Qaradawi (2001, p.15) stated: "The statues made by the elders who came before Islam are part of a historic patrimony. When the Muslims penetrated Afghanistan, in the first century of Hijra, these statues were already there, and they were not destroyed. I advised our brothers of the Taliban movement to reconsider their decision in light of the danger of its negative impact".

For his part, Sabri Abdel Raouf, Chief of the Division of Islamic Studies at Al-Azhar University (Cairo), stated that "statues intended for worship can be forbidden as contrary to Islam but statues that are not worshipped are not forbidden". Through the intervention of Dr. Mufid Shihab, then Minister of Higher Education of Egypt and President of the Egyptian National Commission for UNESCO, to whom as a friend I implored to help finding a solution for this crisis, the UNESCO DirectorGeneral was able to speak with President Hosni Mubarak. He immediately accepted to facilitate a mission of a delegation of Egyptian religious authorities to Kandahar, on March 8, 2001, to persuade the Taliban authorities concerning errors in the interpretation of Islamic Law. I was present when "Sheikh Al-Azhar", the Rector of the oldest Islamic University in Cairo, was proposed as one of the envoys to Afghanistan. I wish to quote President Hosni Mubarak, who at the time stressed: "Mr. DirectorGeneral, not only Sheikh Al-Azhar, but also Mufti Masr will go to Afghanistan, to change the mind of the Taliban!" (personal communication between the President of Egypt, Hosni Mubarak, and the UNESCO Director-General Koïchiro Matsuura on March 8, 2001).

With further invaluable assistance of the Ambassador of Qatar, a religious delegation of 15 personalities was formed and travelled to Afghanistan. It was headed by Dr. Nasr Farid Wassel, Mufti of Egypt, and included the Deputy Secretary-General for Political Affairs of the Organisation of the Islamic Conference, Ibrahim Bakr; Sheikh Yusuf al-Qaradawi, of Doha; Sheikh Mohamed al Raoui, Ulema (scholar) of the Al Azhar University; the well-known Islamic writer Fahmi al-Howaidi; and other specialists in the Sharia (Islamic Law). This delegation, which travelled to Afghanistan in an aircraft provided by H.E. the Emir of Qatar, Hamad bin Khalifa Al Thani, met with the Taliban Minister of Religious Affairs and the Afghan Minister of Foreign Affairs. It was, however, unable to meet Mullah Omar and to convince Afghan religious authorities to abandon plans to demolish the Bamiyan statues. From March 9 to 11, 2001, the world watched as the two Bamiyan Buddhas were destroyed, during the final stages of the Islamic festival of Aïd el Adha.

In my efforts to reach the Head of the Taliban Regime and in hoping to reversing his order, I had been given the name of an Egyptian colleague, who worked for the World Health Organization and was among the very few people to have personally met Mullah Omar. After contacting him and explaining the gravity of the situation, he kindly agreed to write a letter in Arabic to Mullah Omar and to ensure the letter would 
reach him. In his message, he attempted to convince the Taliban leader that such decisions against the cultural heritage of his own country could not be justified by Islam.

I had also established contact with Mrs. Attiya Inayatullah, former Chairperson of the UNESCO Executive Board and then Minister of Social Affairs of Pakistan, with whom I raised the possibility of a direct intervention by President Pervez Musharraf with Mullah Omar. Unfortunately, President Musharraf was not in Islamabad at that time but on pilgrimage to Mecca. Mrs. Inayatullah informed me that she had also been to Kandahar with the Minister of Interior of Pakistan, in a last attempt to convince the Taliban, but that even such desperate mission failed.

In conflict and post-conflict situations, heritage is the object of contradictory tensions between "sanctions" and "reconciliation". On October 17, 2003, a UNESCO Declaration concerning the Intentional Destruction of Cultural Heritage was adopted following the destruction of the two Bamiyan Buddha statues. This Declaration, which is not a binding document but rather a "soft law", reinforced two pre-existing international conventions and two protocols that establish judicial requirements for the protection of cultural heritage. The main purpose of the draft Declaration is threefold: (a) to uphold existing obligations of States under international agreements for the protection of cultural heritage in force; (b) to prevent and prohibit the intentional destruction of cultural heritage and, when linked, natural heritage, in time of peace and in the event of armed conflict; and (c) to encourage States to become party to instruments protecting cultural heritage if they have not already done so (UNESCO 2003).

\section{The Doha Conference}

The experience gained by UNESCO through events in Cambodia, Southeast Europe, Afghanistan, Iraq, the Middle East and Timor-Leste are an indicative hope that a programme can be put in place for the preservation of cultural heritage, with corresponding objectives of reconstruction, on one hand, and dialogue and reconciliation on the other. UNESCO has always considered that archaeological sites, in addition to old manuscripts, in the past are unique witnesses to civilizations. They are frequently associated with ideas or beliefs that have marked the history of humanity since time immemorial.

To respond to the numerous queries that UNESCO received following the destruction of the Bamiyan Buddhas, and to put an end to false interpretations of Islamic law concerning cultural heritage and prevent such idolatry acts in the future, a conference of specialists in Islamic law was organized in Doha (Qatar), from December 29 to 31, 2001, on the occasion of the regular meeting of the Ministers of Culture of the Islamic World.

We started the preparations for this Conference on March 15, immediately after the destruction of the Bamiyan Buddha statues. Contacts were made with the most renowned specialists (Ulama) in Islamic law (Sharia) from different religious schools (Sunna and Shia). Specialists from Morocco, in the western Islamic World, up to Kazakhstan, in its Eastern part, were invited. The main agenda of the 
conference was Islam and Cultural Heritage, and several studies were presented by different scholars.

The Doha Conference of "Ulama" on "Islam and Cultural Heritage" was chaired by His Highness Sheikh Hamad bin Khalifa Al Thani, Emir of the State of Qatar, and put together by the Organization of the Islamic Conference (OIC); the Islamic Educational, Scientific and Cultural Organization (ISESCO); the Arab League Educational, Cultural and Scientific Organization (ALECSO); and UNESCO. It was inaugurated by the Heads of three international and regional organizations: Mr. Koïchiro Matsuura, Mr. Abdulaziz Othman Altwaijri and Mr. Mongi Bousnina. It should be noted that the conference was attended by 27 professors and experts in Islamic Law, from 25 different countries. A delegation from Afghanistan led by Professor Sibghatullah Mujaddidi, former President of Afghanistan, also participated.

After 2 days of intense discussions, this meeting of Ulema gave rise to the "Declaration of Doha", later widely disseminated in Islamic countries. The ulamâ in attendance discussed the various aspects of the subject of the Symposium and in particular the recent destruction of the Buddha in the Bamiyan Valley. They emphasized that the tolerant nature of the Islamic religion requires respect for the human heritage in general, whatever its sources, forms or manifestations. In their deliberations, they highlighted the fact that Muslims have preserved the human heritage in all its diversity, taking care not to harm it in any way. This is attested by the fact that the Islamic world boasts the greater part of the human heritage, most of which goes back to pre-Islamic periods; had it not been preserved by the Muslims, most of those eight heritage sites would have been lost. The ulamâ noted that the situation has remained thus throughout the 14 centuries of the history of Islam. The ulamâ participating in the Symposium affirmed that the "position of Islam with regard to the preservation of the human cultural heritage derives from its appreciation of innate human values and from respect for people's beliefs". They explained that "the position of Islam regarding the preservation of the cultural heritage is a firm position of principle which expresses the very essence of the Islamic religion" (UNESCO 2001).

\section{Cultural Heritage and Post-conflict Reconstruction}

At the request of the UNESCO Director-General, two prominent professors of international law, Prof. Francesco Francioni and Federico Lenzerini, were tasked with preparing a preliminary study on the legal consequences, under international law, of the deliberate destruction of cultural heritage such as that of the great Buddhas of Bamiyan. In their conclusions (Francioni and Lenzerini 2003, p. 650), they stressed the fact that "as the area of fundamental human rights, first, and the area of environmental protection, later, States may no longer invoke their sovereignty and domestic jurisdiction in order to justify acts of deliberate destruction of cultural heritage of great importance for humanity as a whole".

Our analysis has also tried to demonstrate that when such destruction is associated with the intent to discriminate or annihilate another religion and its forms of cultural expression, then the act amounts to a crime of persecution. In contemporary 
international law, the deliberate destruction of cultural heritage of great importance such as the Buddhas of Bamiyan does not only constitute an intolerable offence against the cultural heritage of humanity; when carried out with a discriminatory intent, it also amounts to an attack on the very identity of the targeted people and religion and thus on the dignity and fundamental rights of its members.

Our analysis suggests a more promising trend towards ensuring individual accountability for international crimes. I would like to underline that cultural heritage is increasingly perceived as a priority during post-conflict reconstruction. As referred to by former UNESCO Director-General Koïchiro Matsuura (Matsuura 2002), "the biggest challenge that UNESCO is facing is to make the public authorities, the private sector, and civil society as a whole realize that cultural heritage is not only an instrument for peace and reconciliation, but also a factor of development". This message dates back to 2002, on the occasion of the Year of the United Nations for Cultural Heritage. Almost 20 years later, such statement remains a critical point of reference.

Increasingly, conflicts target symbols of culture in order to destroy the identity of a people. Such form of destruction can often lead the international community to react. In the wake of the destruction of cultural heritage during World War II, the international community responded with the 1954 Hague Convention, followed by two additional protocols. Since then, the nature of warfare has changed, with conflict becoming less a matter of external belligerents and more one of internal conflicts and civil unrest. During such internal conflicts, warring parties often target cultural heritage. The Second Protocol to the 1954 Hague Convention (1999) was written to address the changing nature of conflicts, and the international community must continue to identify proper mechanisms to respond to the growing demand for the preservation of heritage damaged as a result of such conflicts.

A remaining question in Afghanistan and among interested scholars who work or worked in Afghanistan is the future of the Buddhas in the Bamiyan Valley. As we have seen, despite the efforts of the international community and, in particular, the representatives of Islamic countries, the Taliban regime voluntarily destroyed the Bamiyan Valley Buddha statues.

\section{International Seminar in Kabul}

In May 2002, following the fall of the Taliban regime and the coming to power of a new government, UNESCO organized an international seminar in Kabul to assist the launching and coordination of rehabilitation and restoration efforts by the Afghan authorities in charge of the safeguarding the country's cultural heritage, which had been damaged by several years of war. This event, which brought together 107 specialists in Afghan culture and heritage as well as representatives from different scientific institutions and donor countries, was opened by H.E. President Hamid Karzai and chaired by Dr. Makhdoom Raheen, Minister of Information and Culture of Afghanistan. Participants gave presentation on the state of conservation of the Afghan cultural heritage and discussed programmes and coordination for the most 
urgent priorities defined. The seminar resulted in more than seven million US dollars pledged for priority projects, allocated through bilateral agreements and UNESCO Funds-in-Trust projects.

One of the questions raised during a session chaired by President Hamid Karzai concerned the desire, as he stated, expressed by certain Afghans to "reconstruct" "the Buddha statues with the support of foreign contributions" (UNESCO 2002. P. 8). In response to this concern, expressed publicly for the first time to the group of experts gathered in Kabul, the position of UNESCO representatives, supported by ICOMOS, was "the concept of reconstruction was not a priority when humanitarian aid for the Afghan people was urgently needed today" (UNESCO 2002. P. 8). The argument put forward considered, on one hand, that such reconstruction could never be completely authenticity, neither on form nor on materials; on the other hand, experts stressed that the Buddha statues had suffered the ravages of time and that it was virtually impossible to recover such original, historical vision except through the latest photographs and photogrammetry. Furthermore, any reconstruction would necessarily imply the use of reinforced concrete and heavy steel support, and that would ultimately result in a replica totally unrelated to the original.

\section{Bamiyan Expert Working Group}

In 2002, the Bamiyan Expert Working Group was established, and the Government of Afghanistan entrusted UNESCO with the mandate of coordinating all cultural projects in Bamiyan. This Expert Working Group has as its main goal to coordinate the activities carried out in Bamiyan under the various UNESCO projects, as well as any bilateral activities funded by international donors. It also advises the Government of Afghanistan on the implementation of decisions adopted by the World Heritage Committee for the World Heritage property of Bamiyan in the areas of conservation and management.

The 13th Bamiyan Expert Working Group Meeting, held in Tokyo, Japan, in 2017, was of particular importance as there was an interval period of 3 years since the last meeting had taken place, in Orvieto, Italy, in December 2013. The Tokyo meeting initially assessed the progress made on the state of conservation of the property and then set forward prioritized activities for the immediate future in the form of recommendations. These recommendations (UNESCO 2017) included the urgent conservation of the Western Buddha niche, where conservation works had resumed in the second semester of 2016, as well as the need for a revision of the Cultural Master Plan, originally developed in 2004, in view of ever-increasing development pressures. The meeting also served as a platform for preliminary discussions between the Government of Afghanistan, international experts and donor countries on the feasibility of reconstructing at least one of the Buddha statues, which has now been officially requested by the Government of Afghanistan on behalf of the people of Afghanistan. 


\section{Conclusion}

The decision to reconstruct at least one of the Bamiyan Buddha statues remains open to discussion. Different views have been conveyed to the World Heritage Committee, and a final recommendation - to reconstruct or not to - is yet to be made. Besides reconstructing one of the Buddha statues, discussed alternatives included to build a replica and place it in a different location in the valley, away from the presently empty niche, or to display the construct through 3D images, on a screen with pictures of the Buddhas before their destruction.

Much discussion has taken place in Afghanistan and all over the world about the future of this great site, revolving around the question of whether the two giant Buddha statues should be reconstructed. The participants at the First International Seminar on the Rehabilitation of Afghanistan's Cultural Heritage clearly recognized that the first emergency priority is to stabilize the cliff face with its niches and caves (UNESCO 2002). Noting that the decision whether to engage in the reconstruction of the Buddhas statues is a matter to be settled by the Government and people of Afghanistan, it was agreed that reconstruction is not a priority as long as humanitarian aid for the Afghan people is urgently needed (UNESCO 2002). Furthermore, the participants emphasized that the authenticity, integrity and historical importance of this great site need to be memorialized in an appropriate way and that the reconstruction of the statues needs further discussion and careful consideration (UNESCO 2002).

It is my personal belief, which since the awful destruction of the Bamiyan Buddha statues I share with architect Andrea Bruno, that the niches should be preserved as a monument to the crime of their destruction. It is a kind of victory for the monument and a defeat for those who tried to obliterate its memory with dynamite. The Bamiyan World Heritage property should thus be protected as a legacy to future generations and against any further damages.

\section{References}

Bouchenaki, M. (2015). Safeguarding the Buddha statues in Bamiyan and the sustainable protection of Afghan cultural heritage. In B. Cassar \& S. Noshadi (Eds.), Keeping history alive: Safeguarding cultural heritage in post-conflict Afghanistan. UNESCO.

Francioni, F., \& Lenzerini, F. (2003). The destruction of the Buddhas of Bamiyan and international law. European Journal of International Law, 14 (1)(4), 619-651. Oxford University Press.

Gall, C. (2006). From ruins of Afghan Buddhas, a history grows. In New York Times, December 6, 2006. New York: New York Times Company.

Harding, L. (2001). How the Buddha got his wounds. The Guardian. London: Guardian Media Group. 3 March. Retrieved from https://www.theguardian.com/books/2001/mar/03/books. guardianreview2

Matsuura, K. (2002). Address by Mr. Koïchiro Matsuura. On the occasion of the international cultural exchange symposium 2002 commemorating the United Nations year for cultural heritage: The culture of Afghanistan: International cultural exchange and Buddhist culture. Paris: UNESCO. 
Qaradawi, S. Y. (2001). Al Ahram Weekly page 15 dated 21 March 2001 Cairo: Al-Ahram Publishing House.

The Guardian. (2001). Taliban order all statues destroyed in The Guardian. 27 February 2001. London: Guardian Media Group. Retrieved from https://www.theguardian.com/world/2001/ feb/27/afghanistan.rorymccarthy

UNESCO. (1997). Decisions adopted at the 21st session on the World Heritage Committee WHC-97/CONF.208/17. Naples: UNESCO. Retrieved from https://whc.unesco.org/ archive/1997/whc-97-conf208-17e.pdf

UNESCO. (2001). Proceedings of the Doha conference of Ulamâ on Islam and cultural heritage. Paris: UNESCO.

UNESCO. (2002). Conclusions and recommendations. International seminar on the rehabilitation of Afghanistan's cultural heritage in Kabul, 27-29 May 2002. Paris. UNESCO.

UNESCO. (2003). UNESCO declaration concerning the intentional destruction of cultural heritage. In the thirty-second session of the UNESCO general conference. Paris: UNESCO.

UNESCO. (2012). Silk roads: Dialogue, diversity \& development. Paris: UNESCO. Retrieved from https://fr.unesco.org/silkroad/node?page $=71$

UNESCO. (2017). Recommendations. 14th expert working group meeting for the safeguarding of the cultural landscape and archaeological remains of the Bamiyan Valley World Heritage property, Afghanistan. Tokyo, Japan from 1 to 2 October 2017. Paris: UNESCO.

Warikoo, K. (2002). Bamyan: Challenge to world heritage. New Delhi: Bhavana Books \& Prints.

The opinions expressed in this chapter are those of the author(s) and do not necessarily reflect the views of the UNESCO, its Board of Directors, or the countries they represent.

Open Access This chapter is licensed under the terms of the Creative Commons AttributionShareAlike 3.0 IGO License (https://creativecommons.org/licenses/by-sa/3.0/igo/), which permits use, sharing, adaptation, distribution, and reproduction in any medium or format, as long as you give appropriate credit to UNESCO, provide a link to the Creative Commons licence and indicate if changes were made. If you remix, transform, or build upon this chapter or a part thereof, you must distribute your contributions under the same licence as the original. This publication is also available at the UNESCO Open Access Repository: https://unesdoc.unesco.org/

The designations employed and the presentation of material throughout this publication do not imply the expression of any opinion whatsoever on the part of UNESCO concerning the legal status of any country, territory, city or area or of its authorities, or the delimitation of its frontiers or boundaries.

The authors are responsible for the choice and the presentation of the facts contained in this chapter and for the opinions expressed therein, which are not necessarily those of UNESCO and do not commit the Organization. 